\title{
Influence of landscape on assemblages of Chironomidae in Neotropical streams
}

\author{
Debora Sensolo, Luiz Ubiratan Hepp*, Vanderlei Decian and Rozane Maria Restello \\ Programa de Pós Graduação em Ecologia, Departamento de Ciências Biológicas, Universidade Regional Integrada do \\ Alto Uruguai e das Missões - Campus Erechim, Av. Sete de Setembro, 1621, CEP 99700-000, Erechim, Rio Grande do Sul, Brazil
}

Received 9 June 2012; Accepted 13 October 2012

\begin{abstract}
Landscape is important in determining the composition of aquatic assemblage, and benthic invertebrates, particularly Chironomidae, are often used as bioindicators of environmental quality because their occurrence and distribution are influenced by different land uses. The objective of this study was to evaluate the influence of different land uses, considering three landscape scales (drainage basins, riparian buffer and streams), on chironomid assemblage. We sampled streams located in an agricultural matrix by collecting chironomid larvae and water samples and performed a landscape analysis using Geographical Information System techniques. The drainage basins had a high percentage of agricultural land use; in all of the drainage basins studied, 79\% of the riparian buffer was not in accordance with Brazilian law. Cricotopus proved to be a good indicator of the agricultural conditions, whereas Thienemanniella and Rheotanytarsus proved to be indicators of exposed soil. Lopescladius was more sensitive to disturbance and was positively correlated with the presence of riparian vegetation. Although the variables at the local scale (stream) were responsible for a major change in the assemblage, the landscape attributes at large scales (drainage basin and riparian buffer) generated significant effects on Chironomidae fauna. Our results suggest the importance of the conservation of two larger landscape scales to support the equilibrium and maintenance of aquatic assemblage.
\end{abstract}

Key words: Biomonitoring / drainage basin / environmental quality / riparian buffer

\section{Introduction}

Streams are complex networks that are hierarchically organized at large spatial scales (Allan, 2004). Streams reflect the characteristics of their drainage basins, from which they receive large amounts of organic and inorganic matter, forming the basis of the chemical composition of water and the biogeochemical cycles (Barrella et al., 2000). Thus, rivers and streams are natural collectors of landscape and reflect land use in their drainage basins because water features are derived from the environments from which they originate, are stored or percolate (Tundisi and Tundisi, 2008; von Schilleler et al., 2008; Sandin, 2009).

In most lotic environments, the physical and chemical parameters and biological diversity have been altered by anthropogenic inputs, particularly urbanization (Roy et al., 2003; Meyer et al., 2005; Smith and Lamp, 2008; Washburn and Sanger, 2011) and agriculture (Bacey and Spurlock, 2007; Maloney et al., 2008; Hepp and Santos, 2009; Stewart, 2011). Agriculture is an essential activity for

\footnotetext{
*Corresponding author: luizuhepp@gmail .com
}

the production of food, but its consequences include the draining of wetlands, intensive use of agrochemicals and removal of riparian vegetation (Niyogi et al., 2007; Roque et al., 2009; Hepp et al., 2010).

Land-use dynamics, as associated with the intensification of agricultural activities and with the conversion of natural landscapes into changing agricultural landscapes, mainly agricultural matrices, has been considered the main form of human environmental impact. The appropriation of space for farm use without adequate planning and zoning has caused a number of problems on both local and regional levels (Matson et al., 1997). In long-occupied areas, land use and topography are the principal factors in the fragmentation of native vegetation (Hawbaker et al., 2006), and the landscape matrix of most of the areas of intense human activity consist of agriculture or pasture. A matrix can be defined as the longest connected element of the landscape, and it plays a dominant role in its operation; in contrast, a fragment can be considered as a non-linear area with a certain degree of isolation and without direct connectivity (Forman and Godron, 1986). 
The riparian vegetation plays an important role in aquatic ecosystems by providing allochthonous organic matter used as an energy source in the aquatic food chain (Vannote et al., 1980; Barrella et al., 2000). By serving as a barrier to the input of material from the environment, this plant component is also important for the maintenance of water quality (Moulton and Souza, 2006; Stewart, 2011).

Several studies have highlighted the importance of riparian vegetation for maintaining the equilibrium of aquatic assemblage. In a study to observe the effectiveness of riparian vegetation in retaining sediment, Sparovek et al. (2002) found that a 52-m strip would retain up to $54 \%$ of the sediment from the area surrounding the water body, greatly contributing to the maintenance of water quality. Pinder (1995) argued that the presence of riparian vegetation in an aquatic ecosystem results in a significant increase in the area available for colonization by invertebrates and other aquatic organisms. Corbi and TrivinhoStrixino (2008) compared the diversity of Chironomidae in preserved regions with areas of sugar-cane plantations and pasture in Brazil and found that the removal of riparian vegetation results in significant loss of wildlife diversity. Studying the land uses in a watershed, Hepp and Santos (2009) found that sites with urban and agricultural practices caused a decrease in the number of families of Ephemeroptera, Plecoptera and Trichoptera and an increase in the density of Chironomus (Chironomidae). Hepp et al. (2010) observed a difference in the structure and composition of benthic macroinvertebrate fauna in streams in urban and agricultural areas, concluding that sites with riparian vegetation had a higher richness and lower density of pollution-tolerant organisms than sites without riparian vegetation. Washburn and Sanger (2011) reported that the benthic community varies according to stream order and also according to different land uses, such as forested or urban areas. A study by Stewart (2011) in Australia indicated that the removal of riparian vegetation leads to changes in several environmental parameters, including temperature and nutrients, resulting in the loss of sensitive species.

The Chironomidae family comprises bioindicator organisms that are often used to assess water quality (Rosin and Takeda, 2007). This family is a key component of the aquatic food web, converting organic matter into food that is then available to other consumers, and is linked to the decomposition cycle of organic matter (Hepp et al., 2008). In general, chironomids respond efficiently to changes in aquatic ecosystems, and their occurrence and distribution are related to the biogeochemical aspects and heterogeneity of habitats (Rosin and Takeda, 2007; Campbell et al., 2009). Chironomid assemblage have proven to be structured by landscape-level factors, such as specific land uses (Lampert and Allan, 1999; Silver et al., 2004; Kleine and Trivinho-Strixino, 2005; Hepp and Santos, 2009; Roque et al., 2010; Hepp et al., 2010).

Changes in land use in watersheds are considered to be dominant stressors for aquatic ecosystems (Vondracek et al., 2005), and the use of tools based on the georeferencing approach (Geographic Information System, GIS) has positively impacted the monitoring of water resources (Burns, 2005). The economy of southern Brazil (Neotropical region) is concentrated on farming, with large areas used for agricultural activities. Furthermore, the areas of native vegetation, including riparian vegetation, are being increasingly fragmented (Decian et al., 2009; Hepp and Restello, 2010; Hepp et al., 2010). By considering three landscape scales (drainage basin, riparian buffer and streams), this study aimed to evaluate the influence of different land uses on chironomid assemblage. We hypothesized that the effects generated at the local scale (streams) are strong but that the large-scale landscapes (riparian buffer and drainage basin) will generate negative effects on Chironomidae. Furthermore, we hypothesized that chironomid assemblage will be negatively influenced by low percentages of vegetation in the drainage area. We suggest that riparian vegetation alone is not sufficient to ensure water quality in severely degraded landscapes. Furthermore, we expect that the Chironomidae assemblage more closely reflects variations of the physical-chemical water variables. However, changes in the landscape will also influence the composition of bioindicator organisms.

\section{Material and methods}

\section{Study area}

This study was conducted in southern Brazil, between $49^{\circ} 30^{\prime}$ and $54^{\circ} \mathrm{W}$ and $26^{\circ} 30^{\prime}$ and $28^{\circ} 30^{\prime} \mathrm{S}$, in the central/ northern portion of the Uruguay River Basin (Fig. 1). The selected 18 second-order streams are contained in an area with significant agricultural occupation. According to Decian et al. (2009), approximately $77 \%$ of the area is used for anthropogenic activities, and $23 \%$ is covered by native vegetation. The region has altitudes ranging from 400 to $800 \mathrm{~m}$. The climate is classified as Köppen Cfb subtropical temperate, with regular rainfall and well-defined seasons: an annual mean precipitation of $1912 \mathrm{~mm}$ and a mean annual temperature of $17.6^{\circ} \mathrm{C}$ (Bernardi and Budke, 2010). The edaphic and geological formation consists of basalt, and the soil is classified as "EC" (dystrophic Oxisol type) (Hepp et al., 2010). The vegetation is characterized by a mixture of subtropical forest in the Upper Uruguay Basin, along the valleys of the Uruguay River and its tributaries, and Araucaria forest (Budke et al., 2010).

\section{Landscape analysis and environmental variables}

Landscape analysis was conducted based on the geographical coordinates of each sampling site. These points were used to calculate the area of the drainage basin of each of the streams by following the cartographic parameters for the selection of contour points and watersheds. We used the software MapInfo 8.5 and Idrisi 32. The base map used for the study had a scale of 1:35000 


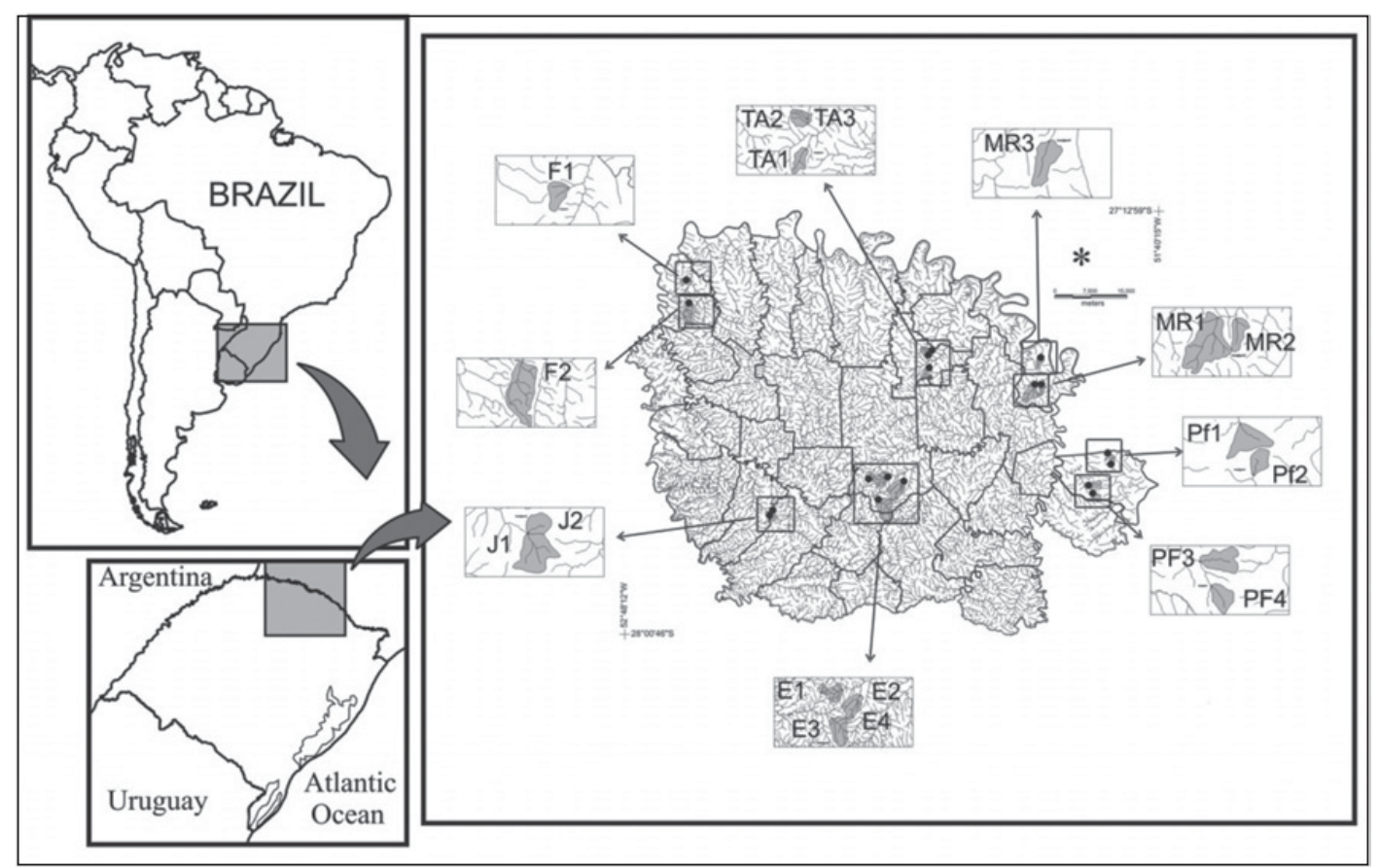

Fig. 1. Location of the sampling sites in the drainage basins studied in southern Brazil.

and was composed of layers and articulated image sensors of Landsat ETM +7 , with a $15-\mathrm{m}$ spatial resolution, spectral bands 3, 4 and 5 and Panchromatic sensitivity. First, we prepared the Numerical Terrain Model, with altitudes of spatialization of $1 \mathrm{~m}$, which were able to demarcate the areas of the drainage basins using the Triangle Irregular Network method. The classification of land use followed the method of Maximum Likelihood Supervised Classification (maxlike) in IDRISI GIS 32 based on the sampling units obtained in the field using GPS, with prior knowledge of the area. The classes used were as follows: agriculture deployed, exposed soil, pasture and woody vegetation. Based on the Spatial Letter of Brazilian Environmental Law and the Charter of Environmental Conflict, a second landscape scale was defined, referred to as a riparian buffer, $30 \mathrm{~m}$ in width, along both banks of the streams.

At each sampling site, the water temperature, dissolved oxygen, electric conductivity and turbidity variables were analysed using a multiparameter analyser (HORIBA ${ }^{\circledR}$ ). Water samples were collected for analysis of the total organic carbon content (TOC) using a SHIMADZU TOC Analyzer ${ }^{\circledR}$, and the nitrite, sulphate and chloride ions were measured using an Ionic-Exchange HPLC ${ }^{\circledR}$.

\section{Sampling and identification of Chironomidae}

The sampling of chironomid larvae was conducted in the summer of 2010 by using a Surber collector (three subsamplings; mesh $=250 \mu \mathrm{m}$; area $=0.1 \mathrm{~m}^{2}$ ) on a rocky substrate. The collections were performed only in the summer because it is a station with greater stability of lotic systems. Moreover, studies in the region show that there is variability in the distribution of aquatic invertebrates during different seasons (Hepp and Santos, 2009; Hepp et al., 2010). Thus, by standardizing the substrate used for the collections, we eliminated the possible effects of this environmental component, allowing us to evaluate the real effects caused by the landscape. Furthermore, this stony substrate constitutes the most abundant and common substrate in all the streams of the study area. For identification, the chironomid larvae were cleared by immersion in a solution of $10 \% \mathrm{KOH}$ for $24 \mathrm{~h}$. The cleared larvae were mounted in Hoyer's solution on glass slides (Trivinho-Strixino and Strixino, 1995) and were examined by using an optical microscope at $1000 \times$ magnification. The larvae were identified to the genus level using the keys and articles by Trivinho-Strixino and Strixino (1995) and Epler (2001).

\section{Data analysis}

Four matrices were organized for data analysis: (i) a biological matrix consisting of the genera and abundance of Chironomidae, (ii) a landscape matrix with the attributes of the drainage basin of each stream, (iii) a riparian buffer matrix and (iv) streams (physical-chemical variables). The biological matrix was transformed into $\log (x+1)$ to ensure homoscedasticity of the data. To evaluate the dependence of the matrices on the drainage basin and riparian buffer, a Mantel test was applied using the landscape attributes of agriculture, exposed soil, 
Table 1. Total area (ha) and percentage of landscape attributes quantified in the drainage basins and riparian buffer of the streams studied in southern Brazil.

\begin{tabular}{|c|c|c|c|c|c|c|c|c|c|c|}
\hline \multirow[b]{2}{*}{ Streams } & \multicolumn{6}{|c|}{ Drainage basin } & \multicolumn{4}{|c|}{ Riparian buffer } \\
\hline & $\begin{array}{l}\text { Drainage } \\
\text { area (ha) }\end{array}$ & $\begin{array}{c}\text { Declivity } \\
(\%)\end{array}$ & $\begin{array}{c}\text { Agriculture } \\
(\%)\end{array}$ & $\begin{array}{c}\text { Exposed soil } \\
(\%)\end{array}$ & $\begin{array}{c}\text { Pasture } \\
(\%)\end{array}$ & $\begin{array}{c}\text { Vegetation } \\
(\%)\end{array}$ & $\begin{array}{c}\text { Agriculture } \\
(\%)\end{array}$ & $\begin{array}{c}\text { Exposed soil } \\
(\%)\end{array}$ & $\begin{array}{c}\text { Pasture } \\
(\%)\end{array}$ & $\begin{array}{c}\text { Vegetation } \\
(\%)\end{array}$ \\
\hline$\overline{\mathrm{PF} 1}$ & 330.2 & 34.8 & 27.1 & 18.6 & 0.0 & 48.2 & 22.6 & 14.8 & 0.0 & 58.5 \\
\hline PF2 & 220.3 & 30.2 & 20.0 & 23.8 & 0.0 & 32.2 & 28.9 & 33.0 & 0.0 & 24.2 \\
\hline PF3 & 81.5 & 24.5 & 24.7 & 49.0 & 0.0 & 21.6 & 25.8 & 57.9 & 0.0 & 16.2 \\
\hline PF4 & 177.6 & 20.2 & 44.5 & 37.2 & 0.0 & 10.8 & 21.3 & 69.3 & 0.0 & 6.1 \\
\hline $\mathrm{F} 1$ & 720.5 & 12.4 & 10.1 & 46.2 & 23.6 & 15.2 & 27.4 & 40.4 & 13.7 & 18.5 \\
\hline $\mathrm{F} 2$ & 132.7 & 16.4 & 20.4 & 14.1 & 47.5 & 17.9 & 29.2 & 17.6 & 22.8 & 30.4 \\
\hline TA1 & 108.8 & 32.5 & 5.8 & 41.7 & 25.9 & 26.6 & 17.0 & 10.4 & 0.1 & 72.5 \\
\hline TA2 & 353.1 & 30.2 & 13.0 & 36.0 & 26.9 & 24.1 & 28.8 & 24.2 & 9.6 & 37.5 \\
\hline TA3 & 322.5 & 29.5 & 24.2 & 20.0 & 31.7 & 24.0 & 33.7 & 16.7 & 0.0 & 49.5 \\
\hline $\mathrm{J} 1$ & 80.3 & 10.8 & 22.5 & 25.2 & 44.9 & 7.4 & 48.2 & 37.0 & 7.2 & 7.6 \\
\hline $\mathrm{J} 2$ & 217.9 & 12.3 & 37.1 & 39.9 & 21.5 & 1.6 & 26.8 & 51.6 & 21.6 & 0.0 \\
\hline ERE1 & 668.3 & 16.5 & 40.4 & 17.8 & 30.8 & 10.9 & 32.8 & 10.4 & 42.5 & 14.4 \\
\hline ERE2 & 1073.2 & 14.6 & 33.5 & 29.9 & 30.3 & 6.2 & 28.6 & 20.9 & 39.0 & 11.5 \\
\hline ERE3 & 199.4 & 12.2 & 19.7 & 24.5 & 39.5 & 16.3 & 38.3 & 35.7 & 5.3 & 20.7 \\
\hline ERE4 & 1284.8 & 16.9 & 27.8 & 36.0 & 28.4 & 7.8 & 29.3 & 31.6 & 24.4 & 14.8 \\
\hline MR1 & 191.2 & 30.6 & 5.9 & 32.8 & 40.2 & 21.1 & 62.1 & 18.7 & 1.7 & 17.5 \\
\hline MR2 & 847.2 & 26.8 & 3.1 & 24.3 & 55.5 & 17.0 & 60.8 & 14.0 & 5.7 & 19.6 \\
\hline MR3 & 270.1 & 26.7 & 0.8 & 31.3 & 45.3 & 22.6 & 72.8 & 7.6 & 0.0 & 19.6 \\
\hline
\end{tabular}

pasture and vegetation in the riparian zone. This test was performed using a matrix of Bray-Curtis dissimilarity correlated with the Pearson correlation coefficient based on 999 permutations.

To assess the variability of chironomid assemblage at the landscape scale, we employed three partial canonical correlation analysis (pCCA; Legendre and Legendre, 2003) using the (i) drainage basin area, (ii) riparian buffer and (iii) streams as explanatory variable matrices. We used the spatial matrix as the geographic coordinate of each collection site. The analysis determined the percentage of explanation provided by the environmental variables (physical-chemical variables and landscape attributes) quantified in the drainage basin, riparian buffer and stream water variables. The variation percentage of each component was obtained from the canonical coefficients generated from the pCCA employed between the biological matrix in relation to the explanatory matrix (drainage basin, riparian buffer and stream) and spatial matrix (Legendre and Legendre, 2003; Melo et al., 2011).

To evaluate the response of the organisms to the variables at larger scales, the main attributes of the landscape (drainage basin and riparian buffer) were analysed separately with a principal components analysis (PCA) to synthesize the information generated by the landscape attributes quantified using a smaller number of principal components. The scores for the first principal component (explaining more than $75 \%$ of the variation) that were used as the explanatory variable in the linear regression analysis of response variables were the richness and abundance of chironomid genera that were the most representative of the community. Analyses were conducted using the package "vegan" (Oksanen et al., 2010) of the R software ( $\mathrm{R}$ Development Core Team, 2010).

\section{Results}

\section{Land-use characterization and environmental variables}

The main land uses in the drainage basins were exposed soil $(30 \%)$, pasture $(30 \%)$, agriculture $(22 \%)$ and woody vegetation $(18 \%)$, totalling more than $80 \%$ of the area with anthropogenic land use (Table 1). The drainage basins with steeper slopes had a comparatively higher percentage of vegetation $(r=0.82, P=0.001)$. However, $79 \%$ of the riparian buffer had very low percentage of native vegetation, which is incompatible with Brazilian law. In the riparian buffer, agriculture and exposed soil comprised the largest percentage of area (Table 1). Although the land used for the riparian buffer is immediately adjacent to the streams, the drainage basins have an intrinsic relationship with the water bodies. The Mantel test between the matrices of the drainage basin and permanent preservation area revealed a dependence between these landscape scales $(r=0.80, P=0.001)$.

Although the water quality was similar in the studied streams (Table 2), the observed changes were reflected in the landscape in the riparian buffer. The water temperature of the streams averaged $22.30 \pm 1.98^{\circ} \mathrm{C}$, was well

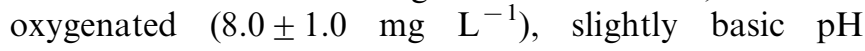
$(8.20 \pm 0.45)$, had a mean electrical conductivity of $0.10 \pm 0.03 \mathrm{mS} \mathrm{cm}^{-1}$ and a turbidity of $1.80 \pm 1.91 \mathrm{NTU}$.

\section{Composition of Chironomidae}

We collected 4222 chironomid larvae in 18 streams. The larvae were identified in 28 genera of three subfamilies (Table 3). Members of Orthocladiinae were the most 
Table 2. Physical-chemical variables (mean, standard deviance [SD], maximum and minimum) of the streams studied in southern Brazil.

\begin{tabular}{|c|c|c|c|c|c|c|c|c|c|}
\hline Streams & $\begin{array}{c}\text { Water } \\
\text { temperature } \\
\left({ }^{\circ} \mathrm{C}\right)\end{array}$ & $\begin{array}{l}\text { Dissolved } \\
\text { oxygen } \\
\left(\mathrm{mg.L^{-1 }}\right)\end{array}$ & $\mathrm{pH}$ & $\begin{array}{l}\text { Conductivity } \\
\left(\mathrm{mS} \mathrm{cm}^{-1}\right)\end{array}$ & $\begin{array}{l}\text { Turbidity } \\
\text { (NTU) }\end{array}$ & $\begin{array}{c}\text { COT } \\
\left(\mathrm{mg}^{-\mathrm{L}^{-1}}\right)\end{array}$ & $\begin{array}{l}\text { Chloride } \\
\left(\mathrm{mg}^{-\mathrm{L}^{-1}}\right)\end{array}$ & $\begin{array}{l}\text { Nitrite } \\
\left(\mathrm{mg}^{-\mathrm{L}^{-1}}\right)\end{array}$ & $\begin{array}{l}\text { Sulphate } \\
\left(\mathrm{mg.L}^{-1}\right)\end{array}$ \\
\hline$\overline{\mathrm{PF} 1}$ & 21.50 & 8.73 & 8.55 & 0.11 & 3.3 & 27.44 & 2.66 & 4.47 & 0.89 \\
\hline PF2 & 22.10 & 9.21 & 8.31 & 0.07 & 0.8 & 37.55 & 2.87 & 6.11 & 0.82 \\
\hline PF3 & 22.50 & 7.24 & 8.33 & 0.07 & 6.4 & 19.31 & 1.83 & 1.52 & 0.49 \\
\hline PF4 & 24.60 & 8.27 & 9.12 & 0.09 & 0.6 & 34.77 & 3.64 & 3.35 & 0.83 \\
\hline $\mathrm{F} 1$ & 21.70 & 7.95 & 7.7 & 0.03 & 1.1 & 335.3 & 1.29 & 1.24 & 0.25 \\
\hline $\mathrm{F} 2$ & 21.10 & 8.01 & 7.13 & 0.01 & 0 & 19.46 & 0.69 & 1.19 & 0.13 \\
\hline TA1 & 21.40 & 9.31 & 8.33 & 0.11 & 1.7 & 24.73 & 3.71 & 5.43 & 1.58 \\
\hline TA2 & 24.30 & 6.57 & 8.33 & 0.12 & 0.5 & 63.39 & 3.27 & 5.76 & 1.08 \\
\hline TA3 & 22.30 & 5.45 & 8.03 & 0.10 & 3.4 & 30.16 & 2.81 & 3.73 & 1.22 \\
\hline $\mathrm{J} 1$ & 22.00 & 7.08 & 7.72 & 0.03 & 0 & 6.73 & 1.13 & 2.32 & 0.17 \\
\hline $\mathrm{J} 2$ & 23.26 & 6.81 & 7.87 & 0.04 & 4.6 & 16.36 & 1.01 & 2.98 & 0.27 \\
\hline ERE1 & 24.30 & 8 & 8.77 & 0.08 & 0 & 14.59 & 1.86 & 2.47 & 0.26 \\
\hline ERE2 & 27.80 & 8.45 & 8.76 & 0.11 & 3.4 & 17.78 & 2.52 & 3.84 & 0.00 \\
\hline ERE3 & 20.31 & 7.91 & 8.37 & 0.05 & 1.2 & 9.63 & 1.45 & 1.52 & 0.25 \\
\hline ERE4 & 20.80 & 8.83 & 8.37 & 0.08 & 4.1 & 40.41 & 2.31 & 2.99 & 0.38 \\
\hline MR1 & 19.90 & 8.61 & 8.24 & 0.08 & 0.4 & 59.19 & 2.27 & 1.02 & 0.72 \\
\hline MR2 & 19.90 & 8.7 & 8.15 & 0.09 & 0.8 & 92.5 & 1.67 & 2.27 & 0.25 \\
\hline MR3 & 21.30 & 8.09 & 8.16 & 0.09 & 0.1 & 77.79 & 2.20 & 1.16 & 0.76 \\
\hline Mean & 22.28 & 7.96 & 8.24 & 0.07 & 1.80 & 51.51 & 2.18 & 2.96 & 0.57 \\
\hline SD & 1.98 & 1.00 & 0.45 & 0.03 & 1.91 & 74.76 & 0.89 & 1.65 & 0.44 \\
\hline Maximum & 27.80 & 9.31 & 9.12 & 0.12 & 6.40 & 335.30 & 3.71 & 6.11 & 1.58 \\
\hline Minimum & 19.90 & 5.45 & 7.13 & 0.01 & 0.00 & 6.73 & 0.69 & 1.02 & 0.00 \\
\hline
\end{tabular}

numerous (2062 individuals, $48.8 \%$ of the total), followed by Chironominae $(1425,33.8 \%)$ and Tanypodinae $(735$, $17.4 \%$ ). Cricotopus Vander Wulp, 1874 was the most abundant genus $(1653,39.2 \%$ of the total), followed by Rheotanytarsus Thienemann and Bause in Bause, 1913 (985, 23.3\%) and Thienemanniella Kieffer, 1911 (548, $13 \%)$. These three genera comprised more than $75 \%$ of the entire fauna of Chironomidae collected in the streams.

\section{Influence of landscape on chironomid assemblages}

The pCCA showed that the environmental component at the three studied scales had the largest variation in Chironomidae assemblage composition (Fig. 2). At the small scale (stream), the environmental variables were responsible for $48.1 \%$ of the variation of the assemblage, whereas the landscape attributes at the two large scales (drainage basin and riparian buffer) explained approximately $25 \%$ of the assemblage variation. The spatial component (geographic coordinates) and the shared component (environment + space) were similar at all three of the scales (Fig. 2). At the small scale, the electrical conductivity and sulphate and nitrite ions were the variables responsible for assemblage variation. At the large scales (drainage basin and riparian buffer), agriculture and exposed soil were the main attributes responsible for assemblage variation (Fig. 3).

The first two principal components calculated from the PCA to synthesize the information generated by the characteristics of the drainage basin explained $91.3 \%$; this high percentage resulted in PC1 representing a gradient of agriculture and exposed soil to all the drainage areas studied. PC1 influenced the abundance of Chironomidae $\left(F_{1,16}=4.83, P=0.04\right)$ and the abundance of Cricotopus $\left(F_{1,16}=4.36, P=0.05\right)$. The PCA calculated using information from the riparian buffer with the first two components explained $85.3 \%$. PC1 influenced the abundance of Chironomidae $\left(F_{1,16}=4.79, \quad P=0.05\right)$ and Thienemanniella $\left(F_{1,16}=4.34, P=0.05\right)$.

The landscape influence features in the drainage basin were dependent on the high percentage of agricultural land use and exposed soil at this landscape scale. This was reflected in the effect of the percentage of agriculture on the total abundance of Chironomidae $\left(F_{1,16}=6.53\right.$, $P=0.02)$ and Cricotopus $\left(F_{1,16}=8.93, P=0.008\right)$ and of the percentage of exposed soil on the abundance of Chironomidae $\left(F_{1,16}=5: 48, P=0.03\right)$ and Rheotanytarsus $\left(F_{1,16}=4.01, P=0.05\right)$ and Thienemanniella $\left(F_{1,16}=7.38\right.$, $P=0.01)$. These results demonstrated the influence of the removal of native vegetation on the genera Cricotopus, Rheotanytarsus and Thienemanniella. In contrast, Lopescladius was positively correlated with the percentage of vegetation in the drainage basins $\left(F_{1,16}=6.24, P=0.02\right)$ and riparian buffer $\left(F_{1,16}=5.22, P=0.03\right)$, and was sensitive to the disturbances caused by agricultural activities.

\section{Discussion}

The greatest variation in the community was generated by the variables obtained at the smallest scale studied (streams). In a way, this is expected because local variables 


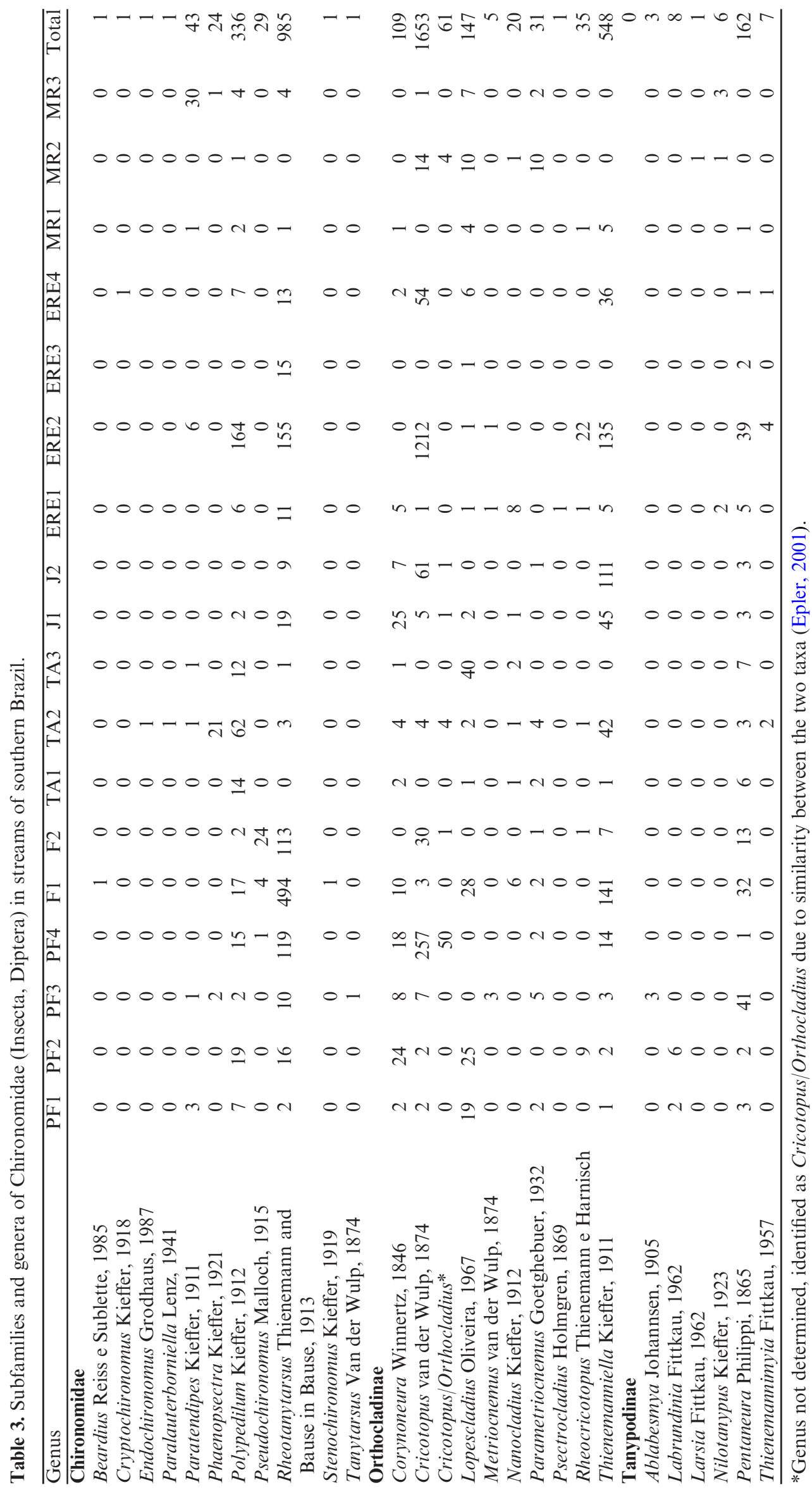




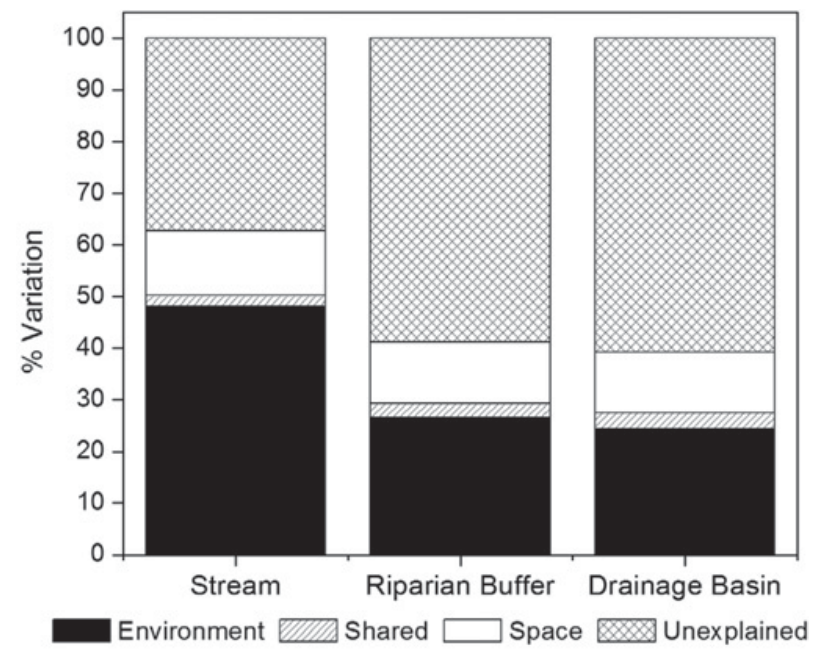

Fig. 2. Per cent of the total variance attributable to the environment, shared component (environment + space), space and unexplained components at stream (physical-chemical variables), riparian buffer and drainage basin scales.

have the greatest effect on the variation of community variables at large scales (Hepp et al., 2012). The results of Lencioni et al. (2012) corroborate the results of the present study; furthermore, the distribution of Chironomidae is greatly influenced by environmental variables at a local scale, which are, in turn, influenced by variables at large scales (Lencioni et al., 2012).

Agriculture contributes to diffuse pollution in aquatic environments, partly due to the changes caused by the removal of riparian vegetation (Kyriakeas and Watzin, 2006). This high percentage of default of a permanent preservation area is mainly a function of the slope: regions with gentler slopes have a higher percentage of agricultural land because such areas are easier to farm. The dependence between the characteristics of the drainage basin and the riparian buffer shows that both landscape scales are important and can be used as indicators of the effects of land use.

Recently, studies conducted in the region assessed the effects of changes in land use on aquatic invertebrate fauna. The results of these studies showed that the point sources of pollution (e.g., urbanization) cause major changes in the abundance, richness and assemblage composition of benthic macroinvertebrates (Hepp et al., 2010). However, when evaluating the effects of non-point sources (e.g., agriculture and exposed soil), the effects are most evident with regard to changes in the composition of communities, which was observed in the present study when considering the composition of chironomid fauna (Hepp and Santos, 2009; Hepp and Restello, 2010).

The family Chironomidae proved to be an efficient bioindicator group for the effects of the landscape near streams because the land uses studied on different scales affected the distribution of this family. According to Sandin (2009), the benthic macroinvertebrate assemblage, including Chironomidae, is structured by environmental factors acting at different spatial scales, and the riparian
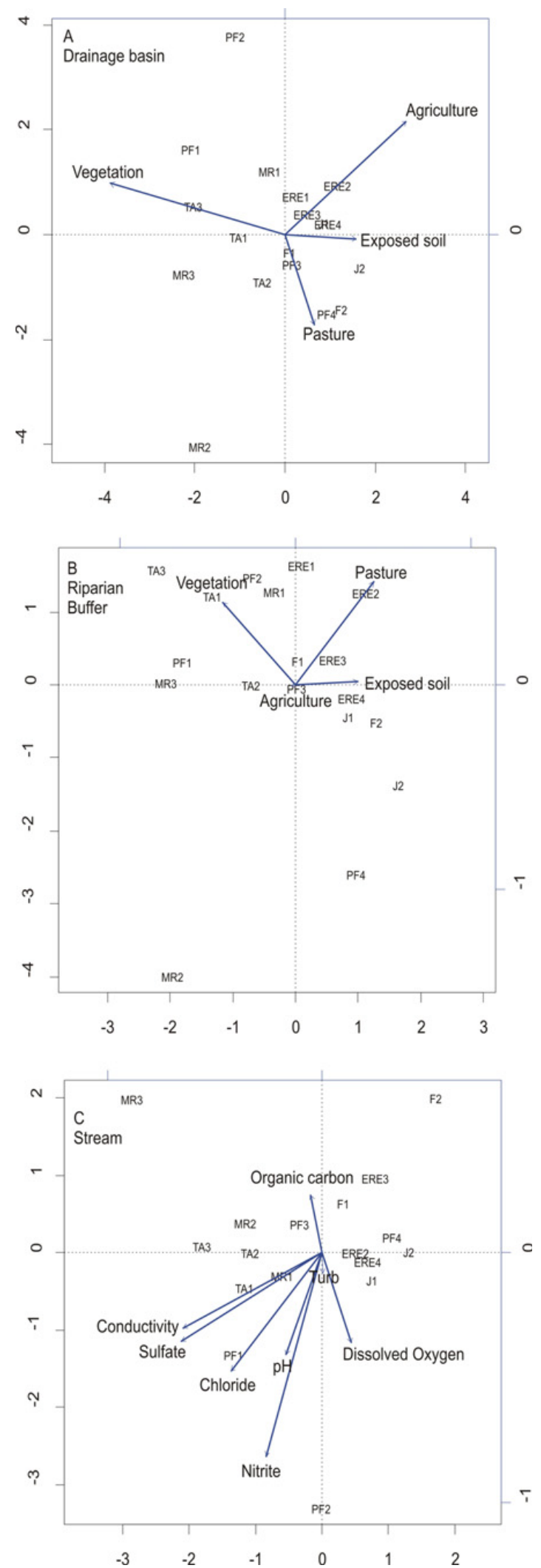

Fig. 3. Diagram biplot of the pCCA between the biological matrix and (a) landscape attribute drainage basin, (b) landscape attribute riparian area and (c) physical-chemical variables in streams. 
vegetation and land use have a strong relationship with community composition, with both being related to the habitat.

The streams with higher percentages of vegetation generally showed a dominance of the genus Lopescladius, which tended to be related to the drainage basins with the largest degree of native vegetation. The presence of preserved riparian vegetation confers great stability and a more-structured fauna, with the presence of stenobiont or less pollution-tolerant groups, such as Lopescladius (Henriques-Oliveira et al., 1999).

Thus, riparian vegetation can significantly influence invertebrate assemblage and proved to be decisive in the composition of aquatic fauna in the present study. Riparian vegetation influences benthic organisms and is an important factor for the colonization of some taxa (Sponseller et al., 2001). The vegetation provides substrate, influencing the composition of benthic macroinvertebrates, including chironomid assemblage (Benstead et al., 2003).

Cricotopus was influenced by the occurrence of catastrophic percentages of agriculture, sites where the streams flowing through the exposed soil areas with no riparian vegetation receive more solar irradiation and, thus, have increased incidence of algal blooms. According to Pinder (1986), members of Cricotopus are tolerant to adverse conditions and may indicate disturbances in the environment. Cricotopus occur mainly in headwaters with little current flow, periphyton or macrophytes and their greater abundance in this study reflected the input of organic matter in the stream.

Thienemanniella and Rheotanytarsus were also positively correlated with agriculture and exposed soil. Members of Thienemanniella are shredders and collectors (Merritt and Cummins, 1996), and several studies have associated Thienemanniella with leaf substrates, in contrast to the present study, which found a negative correlation between this genus and vegetation (Armitage et al., 1995; Henriques-Oliveira et al., 2003). When analysing the benthic macrofauna of rivers under the influence of sugar-cane cultivation in southeastern Brazil, Corbi and Trivinho-Strixino (2008) found Rheotanytarsus in sites with comparatively better water quality. Conversely, some authors have stated that the reason for the high abundance of Rheotanytarsus is unclear but that there is a positive relationship with high levels of water pollution (Simião-Ferreira et al., 2009). In general, the benthic fauna reflects water quality and land use (Resende et al., 2010), and the removal of riparian vegetation strongly influences benthic assemblages (Benstead et al., 2003). For Chironomidae in particular, Benstead and Pringle (2004) argued that the removal of local riparian vegetation adversely affects chironomid assemblage because of decreased food supply.

In conclusion, the variables at the local scale (stream) were responsible for a major change in the community. However, the landscape attributes at larger scales (drainage basin and riparian buffer) generated significant effects on Chironomidae fauna. We observed a strong relationship between the characteristics of the drainage basin and riparian buffer. Although some streams have an extensive drainage basin, the occurrence of vegetation in the drainage basin is important for maintaining stream quality. Only three genera comprised more than $75 \%$ of the total individuals sampled, and these genera were influenced by the negative characteristics of the drainage basins and riparian buffer (percentage of exposed soil and agriculture). Cricotopus proved to be a good indicator of agricultural conditions, whereas Thienemanniella and Rheotanytarsus reflected the presence of exposed soil. In contrast, the more-sensitive genus Lopescladius was positively correlated with the presence of vegetation on both of the large scales studied (drainage basin and riparian buffer). Vegetation in the drainage area of a stream is important when the watershed is heavily degraded. In these cases, riparian vegetation alone is not sufficient to maintain the environmental quality of the streams.

Acknowledgements. Our thanks to the Secretary of Environment of Rio Grande do Sul, Brazil for financial support. Alan Mosele Tonin (URI - Campus Erechim) for help with the analysis of satellite images and quantification of landscape attributes. We thank two anonymous reviewers who gave important suggestions for the qualification of this work. Thanks to Janet Reid for revision of the English text. RMR received financial support from CNPq (Process no. 475251/2009-1). LUH received financial support from CNPq (Process no. 471572/2012.8) and FAPERGS (Process no. 12/1354.0)

\section{References}

Allan J.D., 2004. Landscape and rivers capes: the influence of land use on stream ecosystems. Annu. Rev. Ecol. Syst., 35, 257-284.

Armitage P.D., Cranston P.S. and Pinder L.C.V., 1995. The Chironomidae: Biology and ecology of non-biting midges, Chapman and Hall, London.

Bacey J. and Spurlock F., 2007. Biological assessment of urban and agricultural streams in the California Central Valley. Environ. Monitor. Assess., 130, 483-493.

Barrella W., Petrere Jr M., Smith W.S. and Montag L.F.A., 2000. As relações entre matas ciliares, os rios e os peixes. Cap. 12. In: Rodrigues R.R. and Leitão-Filho H.F. (eds.), Matas Ciliares Conservação e Recuperação. Edusp, São Paulo.

Benstead J.P. and Pringle C.M., 2004. Deforestation alters the resource base and biomass of endemic stream insects in eastern Madagascar. Freshwater Biol., 4, 490-501.

Benstead J.P., Douglas M.M. and Pringle C., 2003. Relationships of stream invertebrate communities to deforestation in eastern Madagascar. Ecol. Appl., 3, 147-149.

Bernardi S. and Budke J.C., 2010. Estrutura da sinúsia epifítica e efeito de borda em uma área de transição entre floresta estacional semidecídua e floresta Ombrófila Mista. Floresta, 40, 81-82.

Budke J.C., Alberti M.S., Zanardi C., Baratto C. and Zanin E.M., 2010. Bamboo dieback and tree regeneration responses in a subtropicalforest of South America. Forest Ecol. Manage., 260, 1345-1349. 
Burns D.A., 2005. Macroinvertebrate response to land cover, habitat, and water chemistry in a mining-impacted river ecosystem: a GIS watershed analysis. Aquat. Sci., 67, 403-423.

Campbell B.D., Haro R.J. and Richardson W.B., 2009. Effects of agricultural land use on chironomid communities: comparisons among natural wetlands and farm ponds. Wetlands, 29, 1070-1080.

Corbi J.J. and Trivinho-Strixino S., 2008. Effects of land use on lotic Chironomid communities of southeast Brazil: emphasis on the impact of sugar cane cultivation. Bol. Mus. Mun. Funchal, Sup., 13, 93-100.

Decian V., Zanin E.M., Henke C., Quadros F.R. and Ferrari C.A., 2009. Uso da terra na região Alto Uruguai do Rio Grande do Sul e obtenção de banco de dados relacional de fragmentos de vegetação arbórea. Perspect., $33,165-176$.

Epler J., 2001. Identification Manual for the Larval Chironomidae (Diptera) of North and South Carolina, Departament of Enviromental a Natural Resources, Orlando.

Forman R.T.T. and Godron M., 1986. Landscape Ecology, John Wiley, New York.

Hawbaker T.J., Radeloff V.C., Clayton M.K., Hammer R.B. and Gonzalez-Abraham C.E., 2006. Road development, housing-growth, and landscape fragmentation in Northing Wisconsin. Ecol. Appl., 16, 1222-1237.

Henriques-Oliveira A.L., Sanseverino A.M. and Nessimian J.L., 1999. Larvas de Chironomidae (Insecta: Diptera) de substrato rochoso em dois rios em diferentes estados de preservação na Mata Atlântica, RJ. Acta Limnol. Brasil., $11,17-28$.

Henriques-Oliveira A.L., Dorvillé L.F.M. and Nessimian J.L., 2003. Distribution of Chironomidae larvae fauna (Insecta: Diptera) on different substrates in a stream at Floresta da Tijuca, RJ, Brazil. Acta Limnol. Brasil., 15, 69-84.

Hepp L.U. and Restello R.M., 2010. Macroinvertebrados bentônicos como ferramenta para avaliação de impactos resultantes dos usos da terra (Rio Grande do Sul, Brasil). In: Santos J.E., Zanin E.M. and Mosquini L.E. (eds.). Faces da Policemia da Paisagem: Ecologia, Planejamento, Percepção, Rima, São Carlos, SP.

Hepp L.U. and Santos S., 2009. Benthic communities of streams related to different land uses in a hydrographic basin in southern Brazil. Environ. Monitor. Assess., 157, 305-318.

Hepp L.U., Biasi C., Milesi S.V., Veiga F.O. and Restello R.M. 2008. Chironomidae (Diptera) larvae associated to Eucalyptus globulus and Eugenia uniflora leaf litter in a subtropical stream (Rio Grande do Sul, Brazil). Acta Limnol. Brasil., 20, 345-350.

Hepp L.U., Milesi S.V., Biasi C. and Restello R.M., 2010. Effects of agricultural and urban impacts on macroinvertebrates assemblages in streams (Rio Grande do Sul, Brazil). Zoologia, 27, 106-113.

Hepp L.U., Landeiro V.L. and Melo A.S., 2012. Experimental assessment of the effects of environmental factors and longitudinal position on alpha and beta diversities of aquatic insects in a Neotropical stream. Int. Rev. Hydrobiol., 97, 157-167.

Kleine P. and Trivinho-Strixino S., 2005. Chironomidae and other aquatic macroinvertebrates of a first order stream: community response after habitat fragmentation. Acta Limnol. Brasil., 17, 81-90.

Kyriakeas S.A. and Watzin M.C., 2006. Effects of adjacent agricultural activities and watershed characteristics on stream macroinvertebrate communities. J. Am. Water Resour. Assoc., 42, 425-441.

Lampert M. and Allan J.D., 1999. Assessing biotic integrity of streams: effects of scale in measuring the influence of land use cover and habitat structure on fish and macroinvertebrates. Environ. Manage., 23, 257-270.

Legendre P. and Legendre L., 2003. Numerical Ecology, Elsevier, Amsterdam.

Lencioni V., Marziali L. and Rossaro B., 2012. Chironomids as bioindicators of environmental quality in mountain springs. Freshwater Sci., 31, 525-541.

Maloney K.O., Feminella J.W., Mitchell R.M., Miller S.A., Mulholland P.J. and Houser J.N., 2008. Land use and small streams: identifying relationships between historical land use and contemporary stream conditions. J. North Am. Benthol. Soc., 27, 280-294.

Matson P.A., Parton W.J., Power A.G. and Swift M.J., 1997. Agricultural intensification and ecosystem properties. Science, 277, 504-509.

Melo A.S., Schneck F., Hepp L.U., Simões N.R., Siqueira T. and Bini L.M., 2011. Focusing on variation: methods and applications of the concept of beta diversity in aquatic ecosystems. Acta Limnol. Brasil., 23, 318-331.

Merritt R.W. and Cummins K.W., 1996. An Introduction to the Aquatic Insects of North America, Dubuque, Kendal/Hunt, USA.

Metzger J.P., 2010. O Código Florestal tem base científica? Nat. Conserv., 1, 92-99.

Meyer J.L., Paul M.J. and Taulbee W.K., 2005. Stream ecosystem function in urbanizing landscape. J. North Am. Benthol. Soc., 24, 602-612.

Moulton T.P. and Souza M.L., 2006. Conservação com base em bacias hidrográficas. In: Rocha C.F.D. (ed.), Biologia da Conservação: Essências. Rima Editora, São Carlos, 157-182.

Niyogi D.K., Koren M., Arbuckle C.J. and Townsend C.R., 2007. Stream communities along a catchment land-use Gradient: subsidy-stress responses to pastoral development. Environ. Manage., 39, 213-225.

Oksanen J., Blanchet F.G., Kindt R., Legendre P., O'Hara R.B., Simpson G.L., Solymos P., Stevens M.H.H. and Wagner H., 2010. Multivariate Analysis of Ecological Communities in R: package "vegan", 2010. http://vegan.rforge. r-project.org/

Pinder L.C.V., 1986. Biology of Freshwater Chironomidae. Annu. Rev. Entomol., 31, 1-23.

Pinder L.C.V., 1995. The habitats of Chironomid larvae. In: Armitage P.D., Cranston P.S. and Pinder L.C.V. (eds.), The Chironomidae: Biology and Ecology of Non-biting Midges, Chapman and Hall, London, 107-135.

R Development Core Team, 2010. $R$ : A language and environment for statistical computing. R Foundation for Statistical Computing, Vienna, Austria. ISBN 3-900051-07-0, http:// www.R-project.org

Roque F.O., Siqueira T. and Escarpinati S.C., 2009. Do fallen fruit-dwelling Chironomids in streams respond to riparian degradation? Pan-Am. J. Aquat. Sci., 4, 357-362.

Roque F.O., Siqueira T., Bini L.M., Ribeiro M.C., Tambosi L.R., Ciocheti G. and Trivinho-Strixino S., 2010. Untangling associations between Chironomid taxa in neotropical 
streams using local and landscape filters. Freshwater Biol., 55, 847-865.

Rosin G.C. and Takeda A.M., 2007. Larvas de Chironomidae (Diptera) da planície de inundação do alto rio Paraná: distribuição e composição em diferentes ambientes e períodos hidrológicos. Acta Sci. Biol. Sci., 29, 57-63.

Roy A.H., Rosemond A.D., Paul M.J., Leigh D.S. and Wallace J.B., 2003. Stream macroinvertebrate response to catchment urbanization (Georgia, USA). Freshwater Biol., 48, 329-346.

Sandin L., 2009. The effects of catchment land-use, near-stream vegetation, and river hydromorphology on benthic macroinvertebrate communities in a south-Swedish Catchment. Fundam. Appl. Limnol., 174, 75-87.

Silver P., Mccall C.B. and Wooster D., 2004. Habitat partitioning by Chironomid larvae in arrays of leaf patches in streams. J. North Am. Benthol. Soc., 23, 467-479.

Simião-Ferreira J., Demarco Jr. P., Mazão G., and Carvalho A.R., 2009. Chironomidae assemblage structure in relation to organic enrichment of an aquatic environment. Neotrop. Entomol., 38, 464-471.

Smith R.F. and Lamp W.O., 2008. Comparison of insect communities between adjacent headwater and main-stem streams in urban and rural watersheds. J. North Am. Benthol. Soc., 27, 161-175.

Sparovek G., Ranieri S.B.L., Gassner A., De-Maria I.C., Schnug E., Santos R.F. and Joubert A., 2002. A conceptual framework for the definition of the optimal width of riparian forests. Agric. Ecosyst. Environ., 90, 169-175.
Sponseller R.A., Benfield E.F. and Vallet H.M., 2001. Relationships between land use, spatial scale and stream macroinvertebrate communities. Freshwater Biol., 4, 14091424.

Stewart B.A., 2011. An assessment of the impacts of timber plantations on water quality and biodiversity values of Marbellup Brook, Western Australia. Environ. Monitor. Assess., 173, 941-953.

Trivinho-Strixino S. and Strixino G., 1995. Larvas de Chironomidae (Diptera) do estado de São Paulo: guia de identificação e diagnose dos gêneros, PP-ERN/UFSCar, São Carlos.

Tundisi J.G. and Tundisi T.M., 2008. Limnologia, Oficina de Textos, São Paulo.

Vannote R.L., Minshall G.W., Cummins K.W., Sedell J.R. and Gushing E., 1980. The river continuum concept. Can. J. Fish Aquat. Sci., 3, 130-137.

Vondracek B., Blann K.L., Cox C.B., Nerbonne J.F., Mumford K.G. and Nerbonne B.A., 2005. Land use, spatial scale, and stream systems: lessons from an agriculture region. Environ. Manage., 36, 775-791.

von Schilleler D., Martin E. and Riera J.L., 2008. Nitrate retention and removal in Mediterranean streams with contrasting land uses: a $15 \mathrm{~N}$ tracer study. Biogeosci. Discuss., 5, 3307-3346.

Washburn T. and Sanger D., 2011. Land use effects on macrobenthic communities in southeastern United States tidal creeks. Environ. Monitor. Assess., 180, 177-188. 